Jurnal Hukum Mimbar Justitia

Fakultas Hukum Universitas Suryakancana

Vol. 4 No. 1 - Juni 2018, hlm. 89-111

ISSN: 2477-5681 (Cetak), ISSN: 2580-0906 (Online)

Open Access at: https://jurnal.unsur.ac.id/jmj

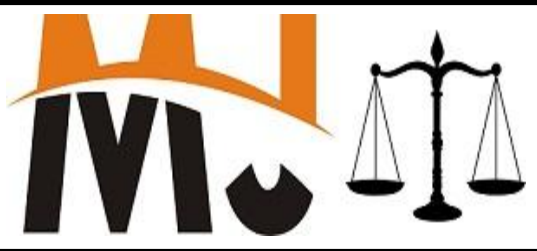

\title{
KONFIGURASI POLITIK DAN KARAKTER HUKUM DALAM PERUMUSAN PERJANJIAN KERJA PERORANGAN DAN PERJANJIAN KERJA BERSAMA
}

\author{
Ahmad Hunaeni Zulkarnaen \\ Universitas Suryakancana \\ E.mail: ahmadhzul@gmail.com
}

Masuk: Maret 2018

Penerimaan: April 2018

Publikasi: Juni 2018

\begin{abstract}
ABSTRAK
Terciptanya ketenanga kerja dan berusaha melalui kejelasan hak dan kewajiban para pihak (pekerja/buruh dan pengusaha), untuk memperjelas hak dan kewajiban para pihak dalam hubungan industrial, baik mengenai hak dan kewajiban bersifat Norma Kerja (Labour Legislation) maupun bersifat Syarat Kerja (Terms of Employment), perlu sarana hubungan industrial berupa Perjanjian Kerja Perorangan (PKP) yang berlaku secara individu dan Perjanjian Kerja Bersama (PKB) yang keberlakuannya secara kolektif. Permasalahan yang diteliti adalah mengenai konfigurasi politik serta syarat sahnya dalam pembuatan PKP dan PKB. Metode penelitian dalam penelitian ini menggunakan deskriptif analitis. Hasil penelitian yang diperoleh bahwa Pembuatan PKP berlaku harus memenuhi syarat sahnya suatu perjanjian sebagaimana diatur dalam Pasal 1320 ayat (1) s.d ayat (4) Kitab Undang-Undang Hukum Perdata (KUHPerdata), dan khusus proses perumusan PKB harus sesuai konsep Negara Kesejahteraan (Welvaartsstaat) dengan karakter produk hukum PKB yang responsif/populistik.
\end{abstract}

Kata kunci : Konfigurasi Politik, Perjanjian Kerja Perorangan, Perjanjian Kerja Bersama.

ABSTRACT
The creation of employment and strive through the clarity of the rights and obligations of the parties (worker/workers and employers), to clarify the rights and obligations of the parties in industrial relations, both regarding the rights and obligations are the norms of work (Labour Legislation) as well as the nature of Work Terms (Terms of Employment), need a means of industrial relations in the form of Individual Work Agreements (PKP) who apply individually and joint work Agreement (PKB) who collectively apply. The problem examined concerns the political configuration of the legitimately in the manufacture of PKP and PKB. Research methods in this study using a descriptive analytical. The research results obtained that the making of PKP applies should be qualified legitimately an agreement as provided for in article paragraph (1) $1320 \mathrm{~s} . d$ subsection (4) the book of the law of civil law (KUHPerdata), and specifically the process of formulation of the PKB should match the concept of the Welvaartsstaat with the character of the legal product PKB responsive/populistik. 
Keywords: Political Configuration, Individual Work Agreements, Joint Work Agreement.

\section{PENDAHULUAN}

Indonesia sebagai negara hukum tercantum dalam Pasal 1 ayat (3) amandemen ketiga Undang-Undang Dasar 1945 yang menyebutkan Indonesia adheres to the principle and the concept of Pancasila contained in the Preamble to 1945 Constitution, ${ }^{1}$ dan dipertegas oleh penjelasan UndangUndang Dasar 1945 (UUD 45), "Indonesia negara yang berdasarkan atas hukum (Rechtsstaat) tidak berdasarkan kekuasaan belaka (Machtsstaat)" dan Indonesia menganut faham Negara Hukum Modern (Welvaartsstaat) tertuang dalam alinea 4 (empat) Pembukaan Undang-Undang Dasar 1945, yang menyebutkan tugas negara adalah "memajukan kesejahteraan umum atau mewujudkan kesejahteraan rakyat", konsep negara hukum Indonesia yang tertuang dalam alinea 4 (empat) Pembukaan UUD 1945 disebut juga konsep Negara Hukum

1 Henny Nuraeny dan Tanti Kirana Utami, 2015, Legal Protection Against Children Who Are Victims of Human Trafficking In Cianjur District Studied By Human Rights Perspective, Jurnal Dinamika Hukum, Vol. 15 No. 2, Mei, hlm. 174.
Modern atau konsep Negara Hukum dalam arti luas atau konsep Negara Kesejahteraan (Welvaartsstaat) sebagaimana dikemukakan oleh F.J. Stahl, seorang sarjana dari Jerman, konsep negara kesejahteraan atau Welvaartsstaat negara mengabdi sepenuhnya kepada, negara satu-satunya untuk menyelenggarakan kemakmuran rakyat, disini negara aktif dalam menyelenggarakan kemakmuran warganya untuk kepentingan seluruh rakyat dan negara. ${ }^{2}$ Teori atau pola negara hukum Indonesia (termasuk prinsip-prinsip dan asas-asasnya) telah disesuaikan dengan kondisi Indonesia berdasarkan falsafah Pancasila, seperti yang dikemukakan oleh Azhary: Kalau konsep negara hukum Eropa kontinental dan konsep negara hukum Anglo Saxon didasarkan kepada paham liberal individualistis, maka konsep negara hukum Indonesia didasarkan pada

2 Padmo Wahjono, 1977, IImu Negara Suatu sistimatik dan Penjelasan 14 Teori IImu Negara dari Jellinek, Melati Study Group, Jakarta hlm. 22. Lihat dalam Ni'matul Huda, 2005, Negara Hukum, Demokrasi dan Judicial Review, UII Press, Yogyakarta, hlm. 8. 
Ahmad Hunaeni Zulkarkaen

Jurnal Hukum Mimbar Justitia

Vol. 4 No. 1 - Juni 2018

pandangan hidup bangsa Indonesia, ${ }^{3}$ yaitu Pancasila. Henny mengatakan bahwa then one as the deciding factor in holding power is the norm or law. ${ }^{4}$

The effectiveness of law enforcement depends on three law aspects; those are the structure of law, the substance of the law, and legal culture. Law structure is about the law enforcers, law substance is about the legislative means, and law culture is about a living law adopted by society. ${ }^{5}$ Tujuan hukum dalam konsep negara hukum Indonesia yang berdasarkan Pancasila sejalan dengan tujuan hukum menurut Roscoe Pound tujuan lain dari pada hukum (selain tujuan hukum untuk memelihara keamanan, ketertiban dan stabilitas masyarakat), adalah kesejahteraan sетиа sетиа warga masyarakat, inilah merupakan cita suatu

3 Azhary, 1995, Negara Hukum Indonesia, Universitas Indonesia, Jakarta, hlm. 143.

4 Henny Nuraeny \& Tanti Kirana Utami, 2016, The Victim Handling Model of Human Trafficking through Economic Independence, Jurnal Dinamika Hukum FH-UNSOED, Vol. 16 No. 2, DOI. 10.20884/1.jdh.2016.16.2.507, hlm. 121.

5 Dedi Mulyadi dan Tanti Kirana Utami, 2017, The Dispute Settlement Model of regional Head Election Perspective Theory of Legal System in Indonesia, International Journal of Nusantara Islam- UIN Sunan Gunung DJati, Vol. 5 No. 1, hlm. 98. negara kesejahteraan (welvaartstaat). ${ }^{6}$ Fokus pada falsafah Pancasila yang menghendaki tercapainya keadilan sosial, sebagaimana secara lebih terperinci dinyatakan oleh UUD 1945, baik di dalam Pembukannya, maupun di dalam Pasal 33 dalam hubungannya dengan Pasal 27 ayat (2), keadilan sosial ini baru akan tercapai, apabila terdapat keseimbangan antara penyelengaraan kebutuhan msyarakat sebagai satu keseluruhan dan kebutuhan perorangan sebagai bagian dari keseluruhan masyarakat itu. ${ }^{7}$

Negara Indonesia adalah negara demokrasi atau kedaulatan berada di tangan rakyat dan dilaksanakan menurut Undang-Undang Dasar (Vide Pasal 1 ayat (2) UUD 1945), sebagai negara yang demokratis Indonesia menganut konfigurasi politik yang demokratis adalah:

"Susunan sistem politik yang membuka kesempatan (peluang) bagi partisipasi rakyat secara penuh untuk ikut aktif menentukan kebijakan umum. Partisipasi ini ditentukan atas dasar mayoritas oleh wakil-wakil rakyat dalam pemilihan-pemilihan berkala didasarkan atas prinsip

\footnotetext{
6 Sunaryati Hartono, 1988, Hukum Ekonomi Pembangunan, Cetakan Kedua, Binacipta, Bandung, hlm. 16-17.

7 Ibid,
} 
Ahmad Hunaeni Zulkarkaen

Jurnal Hukum Mimbar Justitia

Vol. 4 No. 1 - Juni 2018

\begin{abstract}
kesamaan politik dan diselenggarakan dalam suasana kebebasan politik, terdapat pluralitas organisasi di mana organisasi-organisasi penting relatif otonom dan terdapat bagi rakyat melalui wakil-wakilnya untuk melancarkan kritik kepada pemerintah". 8
\end{abstract}

Paham konfigurasi politik yang demokratis, membawa konsekuensi terhadap karakter produk hukum di Indonesia, yaitu menganut karakter produk yang responsif/populistik adalah:

"Produk hukum yang
mencerminkan rasa keadilan dan
memenuhi harapan masyarakat.
Dalam proses pembuatannya
memberikan peranan besar dan
partisipasi penuh kelompok-
kelompok sosial atau individu-
individu di dalam masyarakat.
Hasilnya bersifat responsif
terhadap tuntutan-tuntutan
kelompok sosial atau individu
dalam masyarakat".

Konfigurasi politik yang demokratis dengan karakter produk yang responsif/populistik merupakan konfigurasi politik dan karaktek produk hukum hubungan industrial di Indonesia terutama dalam proses perumusan $\mathrm{PKB}$, istilah hubungan industrial sendiri dikenal dalam dekade

8 Ibid,

9 Ibid,. tahun 2000-an (dua ribuan) sebelum keluarnya Undang-Undang Nomor 13 Tahun 2003 tentang Ketenagakerjaan (UUK),. Sistem hukum hubungan industrial Pancasila berupaya menempatkan pekerja/buruh dengan pengusaha termasuk didalamnya pemerintah dalam kedudukan yang proporsional. $^{10}$

Tujuan dan fungsi hukum (berdasarkan Pancasila dan UUD 1945) sebagaimana telah dipaparkan di atas lebih diarahkan kepada cita-cita untuk kesejahteraan masyarakat Indonesia, baik dalam arti masyarakat sebagai satu kesatuan, maupun kesejahteraan bagi setiap warga negara Indonesia, adalah sejalan dengan tujuan Hubungan Industrial, yang berdasarkan hasil seminar Hubungan Industrial Pancasila (HIP) tahun 1974, tujuan dan fungsi hukum HIP, adalah:

"Mengembangkan cita-cita Proklamasi Kemerdekaan Republik Indonesia 17 Agustus 1945 di dalam pembangunan nasional untuk mewujudkan masyarakat adil dan makmur berdasarkan Pancasila serta ikut

10 Ahmad Hunaeny Zulkarnaen \& Tanti Kirana Utami, 2016, Perlindungan Hukum Terhadap Pekerja Dalam Pelaksanaan Hubungan Industrial, Padjadjaran Jurnal Ilmu Hukum FH-UNPAD, Vol. 3 No. 2, Bandung, hlm. 407. 
melaksanakan ketertiban dunia yang berdasarkan kemerdekaan, perdamaian abadi dan keadilan sosial melalui penciptaan ketenangan, ketentraman dan ketertiban kerja serta ketenangan usaha, meningkatkan produksi dan meningkatkan kesejahteraan pekerja serta derajatnya sesuai derajat manusia. ${ }^{11}$

Suwarto menyatakan, tujuan akhir pengaturan hubungan industrial adalah peningkatan kesejahteraan bagi semua pihak ${ }^{12}$, harus didukung oleh pemerintah. Hal ini selaras dengan pengertian bahwa one of the main factors and actors who play a role in realization of clean government and good governance is bureaucracy. ${ }^{13}$ selanjutnya menurut Suwarto:

"Demi mencapai peningkatan kesejahteraan semua pihak (perusahaan dan kesejahteraan pekerja/buruh: penulis) harus melalui peningkatan produktivitas dari waktu kewaktu. Produktivitas dapat dicapai manakala dalam perusahaan tersebut terjadi keserasian hubungan industrial berdasarkan asas kekeluargaan dan asas kerukunan, sehingga tercipta ketenangan kerja dan berusaha, melalui komunikasi

11 Yunus Shamad, 1995, Hubungan Industrial di Indonesia, PT Bina Sumber-daya Manusia, Jakarta, hlm 12.

12 Suwarto, 2003, Hubungan Industrial Dalam Praktek, Asosiasi Hubungan Industrial Indonesia, hlm 14

13 Ibid,. yang efektif dan berkelanjutan dan dilakukan secara sadar, komunikasi memegang peranan penting dalam membina dan meningkatkan saling percaya.14 Diantara para yang terlibat secara langsung dalam hubungan industrial (pengusaha/pimpinan perusahaan dan pekerja/buruh)".

Pengertian ketenanga kerja dan berusaha di dalam perusahaan atau industrial peace adalah suatu kondisi yang dinamis di dalam hubungan kerja di perusahaan terdapat 3 (tiga) unsur penting, ialah:

1. Hak dan kewajiban terjamin dilaksanakan;

2. Apabila timbul perselisihan dapat diselesaikan secara musyawarah;

3. Mogok dan penutupan perusahaan (lock out) tidak perlu digunakan untuk memaksakan kehendak, karena perselisihan yang terjadi telah dapat diselesaikan dengan baik. $^{15}$

Kondisi dinamis mengandung pengertian (dalam hubungan kerja dan/atau hubungan industrial: penulis) terjadi:

"Komunikasi yang intensif antara pekerja/buruh atau serikat pekerja/serikat buruh dengan

14 Suwarto, 2003, Hubungan......, Op. Cit., hlm 14.

15 Ibid,. 


\section{Ahmad Hunaeni Zulkarkaen \\ Jurnal Hukum Mimbar Justitia \\ Vol. 4 No. 1 - Juni 2018}

pengusaha. Pekerja/buruh atau serikat pekerja/serikat buruh dapat menyampaikan keluhan dan pendapatnya secara bebas dan tanpa ada rasa takut, disamping itu manajemen juga terbuka untuk menampung dan menyelesaikan permasalahan yang dikeluhkannya. Manajemen tingkat lini terdepan harus berperan secara aktif dan positif menampung keluhan yang timbul dan dapat menyelesaikannya sebatas kewenangan yang ada, dan tidak perlu meneruskan keluhan tersebut kepada tingkat yang lebih tinggi". ${ }^{16}$

Pengaturan dan kejelasan hak dan kewajiban bagi pihak-pihak yang terlibat dalam proses produksi merupakan esensi di dalam hubungan industrial. Pengaturan hak dan kewajiban (pihak pengusaha/pimpinan perusahaan dan para pekerja/buruh: penulis) selain dapat dilihat dari peraturan perundang-undangan

(ketenagakerjaan: penulis) yang bersifat Makro Minimal, juga dapat diatur dalam Perjanjian Kerja Perorangan (PKP) yang dibuat oleh perusahaan dan disetujui oleh pekerja/buruh, yang biasanya pembuatan PKP pada saat penerimaan sebagai pekerja/buruh baru. Pengaturan dan kejelasan hak dan kewajiban bagi pihak-pihak selain

16 Ibid, diatur dalam PKP, juga diatur dalam Perjanjian Kerja Bersama (PKB) yang juga mengatur Norma Kerja (labour legislation) dan Syarat-Syarat Kerja (terms of employment) yang bersifat kolektif (kelompok: penulis) pekerja/buruh dan pengusaha tergantung dari cakupan PKB yang bersifat Mikro Kondisional.

Adapun permasalahan yang diteliti meliputi, 1. Bagaimanakah syarat Sahnya Perjanjian dalam pembuatan PKP?; Apakah perumusan PKB menganut konfigurasi politik demokratis dan karakter hukum responsif/populistik?.

\section{METODE PENELITIAN}

Metode pendekatan yang digunakan adalah yuridis normatif, yaitu mempelajari dan mengkaji asasasas, pengertian dan tujuan hukum khususnya kaidah-kaidah hukum positif yang berasal dari bahan-bahan kepustakaan yang ada dari peraturan perundang-undangan serta ketentuanketentuan terutama yang berkaitan dengan syarat sahnya perjanjian kerja perorangan dan konfigurasi politik perumusan serta karakter hukum perjanjian kerja bersama. Dalam 
Ahmad Hunaeni Zulkarkaen

Jurnal Hukum Mimbar Justitia

Vol. 4 No. 1 - Juni 2018

penelitian ini juga meliputi usaha untuk menemukan hukum yang in concreto yang tujuannya untuk menemukan hukum yang sesuai dan yang akan diterapkan dalam suatu permasalahan terutama dalam penelitian tersebut. ${ }^{15}$

Penelitian yang dilakukan merupakan penelitian deskriptif analisis, yaitu memberikan gambaran umum yang menyeluruh dan sistematis mengenai syarat sahnya perjanjian kerja perorangan dan konfigurasi politik perumusan serta karakter hukum perjanjian kerja bersama. Gambaran umum tersebut dianalisis dengan bertitik tolak pada peraturan perundangundangan ketenagakerjaan atau hubungan industrial, pendapat para ahli hukum ketenagakerjaan dan/atau hukum hubungan industrial, dengan tujuan untuk mencari dan mendapatkan jawaban atas pokok masalah yang akan dibahas lebih lanjut dalam penelitian ini.

15 Ronny Hanitijo Soemitro, 1990, Metodologi Penelitian Hukum Dan Jurimetri, Ghalia Indonesia, Jakarta, hlm. 22.
III. HASIL PENELITIAN DAN ANALISIS

\section{A. Syarat Sahnya Perjanjian Kerja Perorangan.}

Hubungan kerja antara pekerja dengan pengusaha tidak selamanya harmonis, ada saja ketidaksepahaman dalam menyikapi hukum ketenagakerjaan. Hal ini menunjukan bahwa in the concept of nation prosperity, not only the government acts as defender of society, but also is responsible to realize the social justice and social prosperity. ${ }^{17}$ Hubungan kerja antara pekerja dengan pengusaha tidak selamanya harmonis, ada saja 94 ketidaksepahaman dalam menyikapi hukum ketenagakerjaan. Hubungan kerja adalah hubungan antara pekerja dengan pengusaha yang terjadi setelah adanya perjanjian kerja. ${ }^{18}$

Dasar dari hubungan kerja adalah perjanjian kerja (perorangan/PKP: penulis), adalah suatu perjanjian (perorangan/PKP: penulis) yang dibuat

17 Tanti Kirana Utami, 2018, Law Protection For Indonesian Migrant Workers Family In Cianjur District, Jurnal Dinamika Hukum FH UNSOED, Vol. 18 No. 2, May, hlm. 158.

18 Tanti Kirana Utami, 2013, Peran Serikat Pekerja Dalam Penyelesaian Perselisihan Pemutusan Hubungan Kerja, Jurnal Wawasan Yuridika STHB, Vol. 28 No. 01, Februari, hlm. 677. 
Ahmad Hunaeni Zulkarkaen

Jurnal Hukum Mimbar Justitia

Vol. 4 No. 1 - Juni 2018

antara pekerja/buruh secara perorangan dengan pengusaha, yang pada intinya memuat hak dan kewajiban masingmasing pihak. Perjanjian kerja dapat dibuat secara lisan atau tertulis, baik untuk (perjanjian kerja; penulis) waktu tidak tertentu (PKWTT: Penulis) maupun untuk (perjanjian kerja: penulis) waktu tertentu (PKWT: Penulis). ${ }^{19}$ Dalam proses PKP berlaku syarat-syarat sahnya suatu perjanjian sebagaimana diatur dalam Pasal 1320 ayat (1) s.d ayat (4) Kitab UndangUndang Hukum Perdata (KUHPerdata), yaitu untuk suatu perjanjian (perjanjian kerja) yang sah harus dipenuhi 4 (empat) syarat:

1. Perizinan yang bebas dari orangorang yang mengikatkan diri;

2. Kecakapan untuk membuat suatu perjanjian;

3. Suatu hal tertentu yang diperjanjikan;

4. Suatu sebab (oorzaak) yang halal, artinya tidak terlarang ${ }^{20}$ tidak dilarang oleh peraturan perundang-undangan, ketertiban umum dan kesusilaan.

19 Suwarto, 2003, Hubungan..., Op.Cit, hlm 42.

20 Subekti, 1984, Pokok-Pokok Hukum Perdata, PT Intermasa, Cetakan Ke XVIII, Jakarta, hlm. 134.

\section{Pasal 1320 ayat (1) KUHPerdata Pada Perjanjian Kerja}

\section{Perorangan}

Pasal 1320 Ayat (1) KUHPerdata, mengatur dalam suatu perjanjian harus ada kesepakatan, pengertian kesepakatan adalah kedua belah pihak (pengusaha/pimpinan perusahan dan pekerja/buruh) dalam suatu perjanjian (perjanjian kerja: penulis), harus mempunyai kemauan bebas untuk mengikatkan diri dan kemauan itu harus dinyatakan. Pernyataan dapat dilakukan dengan tegas atau secara diam-diam. ${ }^{21}$ Cara yang belakangan, sangat lazim dalam suatu perjanjian kerja pernyataan dilakukan dengan tegas, yaitu perjanjian kerja dilakukan secara tertulis, perjanjian kerja secara tertulis (tegas) lebih baik, apabila terjadi salah pengertian akan sangat mudah mencari dasar sebagai acuan penyelesaian, ${ }^{22}$ baik untuk (perjanjian kerja: penulis) waktu tidak tertentu (PKWTT: Penulis) maupun untuk (perjanjian kerja: penulis) waktu tertentu (PKWT: Penulis).

Perjanjian kerja dibuat saat mulai terjadi hubungan kerja, atau pada saat

\footnotetext{
21 Ibid,.

22 Suwarto, 2003, Hubungan..., Op.Cit., hlm 42.
} 
Ahmad Hunaeni Zulkarkaen

Jurnal Hukum Mimbar Justitia

Vol. 4 No. 1 - Juni 2018

pengangkatan pekerja/buruh untuk bekerja disuatu perusahaan. Sehingga dengan demikian sejak awal kedua belah pihak yang terlibat di dalam hubungan kerja telah mengatahui secara tentang hak dan kewajiban masingmasing. ${ }^{23}$

Perjanjian kerja berawal dari adanya pekerjaan yang dimiliki oleh seseorang atau suatu badan yang perlu diselesaikan atau dikerjakan atau perlu dilakukan oleh orang lain yang kemudian menjadi pekerja/buruh. Dengan demikian maka diantara keduanya (pengusaha/pimpinan perusahaan dan pekerja/buruh: Penulis) terjadi suatu ikatan kerja, dimana ikatan tersebut atas dasar kemauan bebas kedua belah pihak, artinya dalam perjanjian kerja tersebut tidak boleh ada unsur paksaan, penipuan dan kehilapan baik dari pihak pekerja/buruh maupun dari pihak pengusaha atau pemberi kerja yang menyangkut objek perjanjian kerja berupa syarat-syarat kerja, hak dan kewajiban.

Paksaan terjadi, jika seseorang (pihak pengusaha/pihak pimpinan perusahaan atau pekerja/buruh: penulis) memberi persetujuannya (dalam suatu

23 Ibid, perjanjian kerja: penulis) karena ia (pihak pengusaha/pihak pimpinan perusahaan atau pekerja/buruh: penulis) akan dianiaya atau akan dibuka rahasianya, jika ia (pihak pengusaha/pihak pimpinan perusahaan atau pekerja/buruh: penulis) tidak menyetujui suatu perjanjian (perjanjian kerja: penulis). Yang diancam harus mengenai suatu perbuatan yang dilarang oleh undang-undang. Jikalau yang diancam itu suatu perbuatan yang memang diizinkan oleh undang-undang, misalnya ancaman akan menggugat yang bersangkutan (pihak pengusaha/pihak pimpinan perusahaan atau pekerja/buruh: penulis) di depan hakim dengan penyitaan barang, itu tidak dapat dikatakan suatu paksaan. ${ }^{21}$

Kekhilafan, dapat terjadi mengani orang (pihak pengusaha/pihak pimpinan perusahaan atau pekerja/buruh: penulis) atau mengenai barang (syarat-syarat kerja, hak dan kewajiban: pemulis) yang menjadi tujuan pihak-pihak (pihak pengusaha/pihak pimpinan perusahaan atau pekerja/buruh: penulis) mengadakan perjanjian $^{22}$ (perjanjian kerja: penulis). Kekhilafan mengenai

\footnotetext{
21 Subekti, 1984, Pokok...Op. Cit, hlm. 135.

22 Ibid,.
} 
Ahmad Hunaeni Zulkarkaen

Jurnal Hukum Mimbar Justitia

Vol. 4 No. 1 - Juni 2018

orang, terjadi misalnya jika seseorang pengusaha/pimpinan perusahaan membuat perjanjian dengan orang yang dikiranya seorang programmer komputer, tetapi kemudian ternyata bukan orang yang dimaksud. Kekhilafan barang, yaitu mengenai syarat-syarat kerja, hak dan kewajiban karena kekhilafan pengusaha/pimpinan perusahaan tidak sesuai peraturan perundangan, misalkan

Pengusaha/pimpinan perusahaan yang mempekerjakan anak (antara usia 13 (tiga belas) tahun sampai dengan 15 (lima belas) tahun) lupa meminta izin dari orang tua atau wali dari pekerja/buruh anak tersebut (Vide Pasal 69 ayat (1) dan ayat (2) UUK).

Penipuan terjadi, apabila satu pihak (pihak pengusaha/pihak pimpinan perusahaan atau pekerja/buruh: penulis) dengan sengaja memberikan keterangan-keterangan yang tidak benar, disertai kelicikan-kelicikan, sehingga pihak lain terbujuk karenanya untuk memberikan perizinan.

\section{Pasal 1320 ayat (2) KUHPerdata Pada Perjanjian Kerja Perorangan}

Pasal 1320 ayat (2) KUHPerdata, mengatur para pihak (subjek) yang membuat perjanjian kerja (pengusaha dan pekerja/buruh) harus memiliki kecakapan untuk membuat suatu perikatan, pengertian kecakapan untuk membuat suatu perikatan menurut Abdulkadir Muhamad, adalah "setiap pihak dalam perikatan (perjanjian kerja: penulis) harus memenuhi syaratsyarat wewenang berbuat menurut hukum atau harus dapat melakukan perbuatan hukum (membuat perjanjian kerja: penulis) yang ditentukan oleh undang-undang, sebagai berikut:

a. Sudah dewasa, artinya sudah berumur 21 tahun penuh;

b. Walaupun belum dewasa tetapi sudah pernah menikah;

c. Dalam keadaan sehat akal (tidak gila);

d. Tidak berada di bawah pengampuan; dan

e. Memiliki surat kuasa jika mewakili pihak lain. ${ }^{23}$

Menurut Subekti, kedua belah pihak (pengusaha/pimpinan perusahaan dan pekerja/buruh: Penulis) harus cakap menurut hukum untuk bertindak sendiri (membuat, menandatangi perjanjian kerja: penulis), beberapa golongan

23 Abdulkadir Muhammad, 2014, Hukum Perdata Indonesia, PT Citra Aditya Bakti, Bandung, hlm 234. 


\section{Ahmad Hunaeni Zulkarkaen \\ Jurnal Hukum Mimbar Justitia \\ Vol. 4 No. 1 - Juni 2018}

orang (pengusaha/pimpinan perusahaan dan pekerja/buruh: Penulis) oleh undang-undang (peraturan perundangundangan: penulis) dinyatakan "tidak cakap" melakukan sendiri perbuatan hukum (membuat, menandatangani perjanjian kerja: penulis). Mereka itu, seperti orang di bawah umur, orang di bawah pengawasan (curatele) dan perempuan (pekerja/buruh perempuan) yang telah kawin (Vide Pasal 1130 KUHPerdata). ${ }^{24}$ atau pejabat perusahaan yang dalam tugas dan kewenangan (job description) tidak diberi tugas dan kewenangan untuk membuat dan menandatangani suatu perjanjian kerja dengan pihak pekerja/buruh, dalam praktek biasanya pejabat yang diberi tugas dan kewenangan (job description) untuk membuat dan menandatangani perjanjian kerja dengan pihak pekerja/buruh adalah pejabat minimal setingkat Kepala Bagian Personalia.

\section{Pasal 1320 ayat (3) KUHPerdata}

\section{Pada Perjanjian Kerja}

\section{Perorangan}

Pasal 1320 ayat (3) KUHPerdata, suatu pokok persoalan tertentu, pokok persoalan tertentu dalam perjanjian

24 Subekti, 1984, Pokok-Pokok Hukum Perdata..., hlm 136. kerja adalah syarat-syarat kerja, hak dan kewajiban dalam suatu hubungan kerja. Syarat-syarat kerja (term of employment) adalah pengaturan hak dan kewajiban bagi pekerja/buruh dan pengusaha/pimpinan perusahaan mengenai berbagai aspek hubungan kerja yang belum diatur yang belum diatur oleh peraturan perundanganundangan (norma kerja). Pengaturan ini bersifat mikro kondisional. Mikro dalam arti diatur hanya untuk perusahaan tertentu secara individual, kondisional dalam arti pengaturan disesuaikan dengan kondisi atau kemampuan perusahaan yang bersangkutan. ${ }^{25}$ Hak-hak pekerja/buruh yang masuk dalam katagori syaratsyarat (term of employment) kerja lebih baik dari hak-hak pekerja/buruh yang masuk dalam katagori norma Kerja (labour legislation), contoh: hak-hak pekerja/buruh yang masuk dalam katagori syarat-syarat kerja (term of employment), adalah: bonus produksi, perumahan untuk pekerja/buruh, tunjangan hari raya idul fitri sebesar 3 (tiga) kali upah perbulan, tunjangan rekreasi, tunjangan naik haji untuk

\footnotetext{
25 Suwarto, 2003, Hubungan..., Op.Cit, 2003, hlm 16.
} 
Ahmad Hunaeni Zulkarkaen

Jurnal Hukum Mimbar Justitia

Vol. 4 No. 1 - Juni 2018

pekerja/buruh yang sudah bekerja selama 10 (sepuluh) tahun, tunjangan umroh untuk pekerja/buruh yang sudah bekerja 5 (lima) tahun dan lain-lain.

Norma kerja (labour legislation), adalah pengaturan hak dan kewajiban untuk pekerja/buruh dan pengusaha/pimpinan perusahaan yang tertuang di dalam peraturan perundangundangan (ketenagakerjaan: penulis), bersifat imperatif dan harus dilaksanakan. Karena sifatnya wajib maka mengikat semua perusahaan bersifat Makro Minimal. Makro dalam arti mengikat perusahaan tanpa kecuali baik tempat, ukuran, jenis usaha, sifat badan hukum, dan lain sebagainya, dan minimal dalam arti bahwa dalam praktek mengenai hal-hal yang diatur dapat dilaksanakan lebih baik atau lebih atau lebih besar tergantung kemampuan dan kemauan perusahaan secara individual. $^{26}$

Norma kerja (labour legislation) dalam penggolongan hukum berdasarkan sifat dan kekuatan sanksinya, masuk kaidah hukum memaksa (dwingendrecht, compulsory law), yaitu kaidah-kaidah hukum yang berisi ketentuan-ketentuan hukum yang

26 Ibid,

$\begin{array}{llr}\text { dalam keadaan } & \text { apapun } & \text { pada } \\ \text { kenyataannya } & \text { tidak } & \text { dapat }\end{array}$

dikesampingkan melalui perjanjian individual yang dibuat di antara para pihak. Dengan kata lain kaidah-kaidah hukum semacam ini dalam keadaan apapun harus ditaati dan daya ikatnya bersifat mutlak. ${ }^{27}$ Berdasarkan isi kaidahnya norma kerja (labour legislation) masuk dalam kaidah hukum publik, adalah kaidah-kaidah hukum yang mengatur hal-hal ketatanegaraan, khususnya yang menyangkut cara-cara, antara lain "perwujudan hubungan hukum antara pemerintah (negara) dengan masyarakat $^{28}$ pengusaha/pimpinan perusahaan dan pekerja/buruh.

Hak dan kewajiban yang di atur dalam norma kerja (labour legislation), berbeda dengan pengertian hak dan kewajiban yang diatur dalam hukum perdata/privat/sipil:

a. Hak dan kewajiban yang diatur dalam hukum perdata/privat/sipil pada dasarnya sama-sama merupakan pernanan. Peranan yang dimaksud adalah terletak

\footnotetext{
27 Tim Pengajar PIH Fakultas Hukum Unpar, 1995, Pengantar Ilmu Hukum, Bandung, hlm. 67.

28 Ibid., hlm. 69.
} 
Ahmad Hunaeni Zulkarkaen

Jurnal Hukum Mimbar Justitia

Vol. 4 No. 1 - Juni 2018

pada pelaksanaan atas hak dan kewajiban itu sendiri. Terhadap peranan yang boleh tidak dilaksanakan itu nama hak, sehingga sifatnya fakultatif (kebolehan), sedangkan pernanan yang harus dilaksanakan dikatakan sebagai kewajiban sehingga sifatnya imperatif (keharusan). ${ }^{29}$ Hak dan kewajiban yang diatur dalam hukum perdata/privat/sipil bila dilihat dari penggolongan hukum yang berdasarkan sifat dan kekuatan sanksinya masuk dalam kaidah hukum mengatur (aanvullendrecht), yaitu kaidahkaidah hukum yang dalam kenyataannya dapat dikesampingkan oleh para pihak dengan membuat ketentuanketentuan atau aturan-aturan khusus di dalam perjanjian yang mereka adakan sendiri, kaidahkaidah hukum semacam ini baru akan berlaku (dan karena itu jadi memaksa) dalam hal para pihak tidak menetapkan peraturan-

29 Muhamad Erwin, H Firman Freaddy Busroh, 2012, Pengantar Ilmu Hukum, akan ke 1 (satu) PT Refika Aditama, Bandung, hlm 39. peraturan sendiri di dalam perjanjian yang mereka adakan. ${ }^{30}$

b. Hak dan kewajiban pengusaha serta pekerja/buruh yang diatur dalam norma kerja (labour legislation) berdasarkan penggolongan hukum serta sifat dan kekuatan sanksinya, masuk kaidah Hukum yang memaksa (dwingendrecht, compulsory law), yaitu kaidah-kaidah hukum yang berisi ketentuan-ketentuan hukum yang dalam keadaan apapun pada kenyataannya tidak dapat dikesampingkan melalui perjanjian individual yang dibuat di antara para pihak. Dengan kata lain kaidah-kaidah hukum semacam ini dalam keadaan apapun harus ditaati dan daya ikatnya bersifat mutlak. ${ }^{31}$ Berdasarkan isi kaidahnya norma kerja (labour legislation) masuk dalam kaidah hukum publik, adalah kaidah-kaidah hukum yang mengatur hal-hal ketatanegaraan, khususnya yang menyangkut caracara, antara lain "perwujudan

30 Tim Pengajar PIH Fakultas Hukum Unpar, 1995, Pengantar Ilmu Hukum..., Op.Clt, hlm. 68.

31 Ibid., hlm. 67. 
Ahmad Hunaeni Zulkarkaen

Jurnal Hukum Mimbar Justitia

Vol. 4 No. 1 - Juni 2018

$\begin{array}{llr}\begin{array}{l}\text { hubungan } \\ \text { pemerintah }\end{array} & \begin{array}{l}\text { hukum } \\ \text { (negara) }\end{array} & \begin{array}{l}\text { antara } \\ \text { dengan }\end{array} \\ \text { masyarakat. }^{32} & & \end{array}$

4. Pasal 1320 ayat (4) KUHPerdata

Pada Perjanjian Kerja

\section{Perorangan}

Pasal 1320 ayat (4) KUHPerdata menghendaki untuk suatu perjanjian (PKP: penulis) harus ada suatu "oorzaak" atau "causa" berarti "sebab" atau "tujuan" yaitu apa yang dikendaki oleh para pihak (pengusaha/pimpinan perusahaan, pekerja/buruh: penulis) dengan perjanjian (PKP: penulis) itu. Misalnya dalam PKP para pihak minimal harus melaksanakan hak dan kewajiban yang bersifat Norma kerja (labour legislation), yaitu pengaturan hak dan kewajiban untuk pekerja/buruh dan pengusaha/pimpinan perusahaan yang tertuang di dalam peraturan perundangundangan (ketenagakerjaan: penulis), bersifat imperatif dan harus dilaksanakan. Dengan kata lain causa berarti: isi perjanjian (PKP: penulis) itu sendiri. $^{34}$

Menurut Pasal 1335 KUHPerdata, suatu perjanjian (PKP: penulis) yang

\footnotetext{
32 Ibid., hlm. 69.

34 Subekti, 1984, Pokok-Pokok Hukum Perdata..., Op.Cit., hlm. 136-137.
}

tidak memakai causa atau dibuat dengan suatu causa yang palsu atau terlarang tidak mempunyai kekuatan. Berdasarkan paparan di atas, jelaslah bahwa praktis hampir tidak ada perjanjian (PKP: penulis) yang tidak mempunyai causa. Suatu causa yang palsu terdapat, jika suatu perjanjian (PKP: penulis) dibuat dengan pura-pura saja, untuk menyembunyikan causa yang sebenarnya yang tidak diperbolehkan, ${ }^{35}$ contoh: causa yang pura-pura juga bertentangan dengan peraturan perundang-undangan ketenagakerjaan, yaitu: pengusaha/pimpinan perusahaan seolaholah membayar upah pekerja/buruhnya minimal sesuai upah minimum, padahal kenyataannya upah pekerja/buruhnya dibayar di bawah upah minimum di kabupataen atau kota dimana PKP dibuat.

Causa dalam suatu perjanjian (PKP: penulis) ialah yang tidak bertentangan dengan peraturan perundang-undangan, kesusilaan atau ketertiban umum, suatu causa PKP yang bertentangan dengan peraturan perundang-undangan ketenagakerjaan misalnya, suatu PKP dimana pihak

35 Ibid 
pengusaha/pimpinan perusahaan dan pekerja/buruh sepakat untuk besaran upah pekerja/buruhnya dibawah upah minimum di kabupaten atau kota dimana PKP dibuat, PKP tersebut bertentangan dengan Pasal 88 ayat (3) huruf a UUK yang mewajibkan pengusaha/pimpinan perusahaan untuk membayar pekerja/buruhnya minimal sebesar upah minimum kabupaten/kota dimana perusahaan tersebut berada (berdomisili). PKP yang bertentangan dengan kesusilaan, misalnya pengusaha/pimpinan perusahaan mau menerima seseorang untuk bekerja diperusahaan dengan syarat orang (pekerja/buruh) tersebut selama dalam jam kerja dilarang untuk melaksanakan ibadah menurut agama atau keyakinannya. Dalam hal-hal (PKP: Penulis) semacam ini, perjanjian (PKP: penulis) itu dianggap dari semula sudah batal (demi hukum: penulis) dan hakim berwenang-karena jabatannyamengucapkan pembatalan-meskipun tidak diminta oleh para pihak (pengusaha/pimpinan perusahaan, pekerja/buruh: penulis) atau batal secara mutlak. ${ }^{36}$

${ }^{36} \mathrm{Ibid}$,
Pasal 1338 ayat (1) KUHPerdata, mengatur "Semua persetujuan (PKP: penulis) yang dibuat secara sah sesuai dengan undang-undang berlaku sebagai undang-undang bagi mereka yang membuatnya atau dengan kata lain mengikat para pihak (pengusaha/pimpinan perusahaan, pekerja/buruh). Perjanjian (PKP: penulis) tidak dapat ditarik kembali, kecuali dengan persetujuan kedua belah pihak (pengusaha/pimpinan perusahaan, pekerja/buruh: penulis) atau berdasarkan alasan-alasan yang ditetapkan oleh undang-undang (peraturan perundangundangan:penulis).

\section{B. Konfigurasi Politik Perumusan dan Karakter Hukum Perjanjian Kerja Bersama.}

1. Konfigurasi Politik Perumusan Perjanjian Kerja Bersama.

Telah dipaparkan di atas, PKP berlaku secara individu, yaitu hanya mengikat pengusaha/pimpinan perusahaan dan pekerja/buruh secara individu, PKP dibuat pada saat baru pertama kali seseorang diterima sebagai pekerja/buruh di suatu perusahaan. Sedangkan Perjanjian Kerja Bersama (PKB) keberlakuannya secara kolektif 


\section{Ahmad Hunaeni Zulkarkaen \\ Jurnal Hukum Mimbar Justitia \\ Vol. 4 No. 1 - Juni 2018}

(kelompok) yaitu PKB berlaku untuk semua pihak yang terlibat secara langsung dalam hubungan kerja atau hubungan industrial (pengusaha/pimpinan perusahaan dan seluruh pekerja/buruh) pada perusahaan dimana PKB dibuat, $\mathrm{PKB}$ dibuat pada masa pekerja/buruh selama bekerja (during employment).

PKB merupakan salah satu sarana dalam rangka pelaksanaan terjadinya keserasian hubungan berdasarkan asas kekeluargaan dan kerukunan dalam suatu hubungan industrial, sekaligus sebagai sarana untuk menciptakan ketenangan kerja dan berusaha dalam perusahaan atau industrial peace. $\mathrm{PKB}$ merupakan salah satu sarana dalam rangka pelaksanaan hubungan industrial yang serasi, aman mantap dan dinamis berdasarkan Pancasila (Vide huruf a Pertimbangan Peraturan Menteri Tenaga Kerja Nomor 01 Tahun 1985 tentang Pelaksanaan Tata Cara Pembuatan Kesepakatan Kerja Bersama/Permenaker 01/1985).

PKB dibuat oleh serikat pekerja/serikat buruh atau beberapa serikat pekerja/serikat buruh yang telah tercatat pada instansi yang bertanggung jawab di bidang ketenagakerjaan dengan pengusaha atau beberapa pengusaha, penyusunan $\mathrm{PKB}$ dilakukan secara musyawarah (Vide Pasal 116 ayat (1) dan ayat (2) UUK). PKB adalah perjanjian yang merupakan hasil perundingan antara serikat pekerja/serikat buruh atau beberapa serikat pekerja/serikat buruh yang tercatat pada instansi yang bertanggung jawab di bidang ketenagakerjaan dengan pengusaha, atau beberapa pengusaha atau perkumpulan pengusaha yang memuat syarat-syarat kerja, hak dan kewajiban kedua belah pihak (Vide Pasal 1 ayat (2) Peraturan Menteri Tenaga Kerja Nomor 28 Tahun 2014 tentang Tata Cara Pembuatan Peraturan Perusahaan Serta Pembuatan dan Pendaftaran Perjanjian Kerja Bersama/ Permenaker 28/2014).

Proses perumusan PKB yang mengharuskan dirundingkan dantara serikat pekerja/serikat buruh atau beberapa serikat pekerja/serikat buruh dengan Pengusaha, atau beberapa pengusaha atau perkumpulan pengusaha, kalau meminjam istilah Moh. Mahfud MD, maka proses perumusan $\mathrm{PKB}$ menganut konfigurasi politik demokratis, karena proses perumusannya membuka kesempatan 
Ahmad Hunaeni Zulkarkaen

Jurnal Hukum Mimbar Justitia

Vol. 4 No. 1 - Juni 2018

(peluang) bagi partisipasi baik kepada pengusaha maupun seluruh pekerja/buruh melalui serikat pekerja/serikat buruh secara penuh ikut aktif dalam menentukan syarat kerja (term of employment) yang akan dituangkan dalam PKB, partisipasi serikat pekerja/serikat buruh dalam proses perumusan $\mathrm{PKB}$ selain untuk meningkatkan produktivitas perusahaaan, juga untuk mewujudkan tujuan dari serikat pekerja/serikat buruh, yaitu antara lain meningkatkan kesejahteraan pekerja/buruh dan keluarganya.

Proses perumusan PKB menganut konfigurasi politik demokratis, yaitu proses perumusannya melibatkan serikat pekerja/serikat buruh, yaitu suatu organisasi yang dibentuk dari, oleh, dan untuk pekerja/buruh baik di perusahaan maupun di luar perusahaan, yang bersifat bebas, terbuka, mandiri, demokratis, dan bertanggung jawab guna memperjuangkan, membela serta melindungi hak dan kepentingan pekerja/buruh serta meningkatkan kesejahteraan pekerja/buruh dan keluarganya (Vide Pasal 1 ayat (1) Undang-Undang Nomor 21 Tahun 2000 tentang Serikat Pekerja/Serikat
Buruh, selanjutnya disebut UU Serikat Pekerja). Supaya keberadaan PKB betul-betul dapat menjadi salah satu sarana hubungan industrial dengan tujuan meningkatkan produktivitas perusahaan yang berkorelasi dengan peningkatan kesejahteraan pekerja/buruh dan keluarganya, maka hasil perumusan PKB harus lebih banyak memuat kondisi kerja (working condition) berupa syarat kerja (term of employment) bukan hanya sekedar norma kerja (labour legislation).

Kondisi kerja (working condition) merupakan tingkat keadaan ketenagakerjaan yang dilihat dari pengaturan hak dan kewajiban antara pekerja/buruh dan pengusaha/pimpinan perusahaan. $^{37}$ Norma kerja (labour legislation), pengaturan hak dan kewajiban bagi pekerja/buruh dan pengusaha/pimpinan perusahaan yang tertuang di dalam peraturan perundangundangan. Sifat pengaturannya imperative atau harus dilaksanakan, wajib, mengikat semua perusahaan tanpa kecuali baik tempat, ukuran, jenis usaha, sifat badan hukum, dan lain sebagainya, dan minimal dalam arti bahwa dalam praktek mengenai hal-hal

37 Suwarto, 2003, Hubungan...Op.Cit, hlm. 15. 
Ahmad Hunaeni Zulkarkaen

Jurnal Hukum Mimbar Justitia

Vol. 4 No. 1 - Juni 2018

yang diatur dalam dapat dilaksanakan lebih baik atau lebih besar tergantung kemampuan dan kemauan perusahaan secara individual dalam suatu Syarat kerja (term of employment). ${ }^{38}$

Syarat kerja (term of employment) adalah pengaturan hak dan kewajiban bagi pekerja/buruh dan pengusaha/pimpinan perusahaan mengenai berbagai aspek hubungan kerja yang belum diatur atau tidak diatur oleh peraturan perundangundangan (norma kerja). Pengaturan ini bersifat mikro-kondisional. Mikro dalam arti diatur hanya untuk perusahaan tertentu secara individual. Kondisional dalam arti pengaturan disesuaikan dengan kondisi atau kemampuan perusahaan yang bersangkutan. ${ }^{39}$

\section{Konfigurasi politik (politik} hukum: penulis) menurut Moh. Mahfud MD akan menentukan karakter produk hukum, konfigurasi politik yang demokratis akan menghasilkan produk hukum responsive/populistic, sementara konfigurasi politik yang otoriter akan menghasilkan karakter hukum konservatif/ortodoks/elitis. $^{40}$ Mengacu kepada pendapat Moh. Mahfud MD di atas, yaitu konfigurasi politik dalam perumusan PKB yang demokratis akan menghasilkan produk hukum PKB responsive/populistic dan konfigurasi politik dalam perumusan $\mathrm{PKB}$ yang otoriter akan menghasilkan karakter hukum konservatif/ortodoks/elitis.

Politik hukum adalah "kebijakan dasar yang menentukan arah, bentuk maupun isi hukum yang akan dibentuk. ${ }^{41}$ Politik hukum PKB adalah kebijakan dasar yang dibuat oleh pengusaha/pimpinan perusahaan dengan para pekerja/buruh (serikat pekerja/serikat buruh) yang akan menentukan arah, bentuk maupun isi PKB yang akan dibentuk sesuai konfigurasi politik yang dianut oleh politik hukum PKB tersebut.

Konfigurasi politik diartikan sebagai susunan atau konstelasi kekuatan politik yang dikotomis dibagi atas dua konsep yang bertentangan secara diametral, yaitu konfigurasi

40 Moh. Mahfud MD, 2010, Politik Hukum di Indonesia, Edisi Revisi, Rajawali Pers, Jakarta, hlm 31-32.

41 Padmo Wahyono, dalam Bernad L. Tanya, 2011, Politik Hukum Agenda Kepentingan Bersama, Genta Publishing, Yogyakarta, hlm. 3. 
Ahmad Hunaeni Zulkarkaen

Jurnal Hukum Mimbar Justitia

Vol. 4 No. 1 - Juni 2018

politik demokratis dan konfigurasi politik otoriter. Pengertian konsepsual dan indikator-indikator variable bebas adalah:

a. Konfigurasi politik demokratis adalah susunan sistem politik yang membuka kesempatan (peluang) bagi partisipasi rakyat secara penuh ikut aktif menentukan kebijakan umum. Partisifasi ini ditentukan atas dasar mayoritas oleh wakil-wakil rakyat dalam pemilihan-pemilihan berkala yang didasarkan atas prinsip kesamaan politik dan diselenggarakan dalam suasana terjadinya kebebasan politik, di dalam konfigurasi politik demokratis ini terdapat kebebasan bagi rakyat melalui wakilwakilnya untuk melancarkan kritik terhadap pemerintah.

b. Konfigurasi politik otoriter adalah susunan sistem politik yang lebih memungkinkan negara berperan aktif serta mengambil hampir seluruh inisiatif dalam membuat suatu kebijakan negara.

Konfigurasi ini ditandai oleh dorongan elit kekuasaan untuk memaksakan persatuan.
Penghapusan oposisi terbuka, dominasi pimpinan negara untuk menentukan kebijakan negara dan dominasi kekuasaan politik oleh elit politik yang kekal, serta di balik semua itu ada satu doktrin yang membenarkan konsentrasi kekuasaan. ${ }^{42}$

Secara spesifik, untuk mengkualifikasikan apakah konfigurasi politik (politik hukum PKB: Penulis) itu demokratis atau otoriter, indikator yang dipakai adalah perumusan PKB membuka kesempatan (peluang) bagi partisipasi para pekerja/buruh atau serikat pekerja/serikat buruh dan pengusaha/pimpinan perusahaan secara penuh ikut aktif menentukan arah, bentuk maupun isi PKB yang disepakati bersama secara musyawarah disesuaikan dengan kondisi atau kemampuan perusahaan yang bersangkutan (mikro conditional).

\section{Karakter Produk Hukum}

\section{Perjanjian Kerja Bersama}

Meminjam istilah dari Moh. Mahfud MD, tentang "Karakter Hukum" . ${ }^{43}$ Produk hukum (PKB: Penulis) yang responsive/populistik

42 Moh. Mahfud MD, 2010, Politik Hukum..., hlm. 31.

43 lbid, 
Ahmad Hunaeni Zulkarkaen

Jurnal Hukum Mimbar Justitia

Vol. 4 No. 1 - Juni 2018

adalah produk hukum (PKB: Penulis) yang mencerminkan rasa keadilan dan memenuhi harapan masyarakat (pengusaha, pekerja/buruh, pemerintah: penulis), dimana dalam proses pembuatannya memberikan peranan besar dan partisipasi penuh kelompokkelompok sosial atau individu-individu di dalam masyarakat (pengusaha, pekerja/buruh, pemerintah: penulis), dan hasilnya bersifat responsive terhadap tuntutan semua pihak, sehingga mampu mewujudkan tujuan akhir pengaturan hubungan industrial yaitu kesejahteraan bagi semua pihak yaitu produktivitas/keuntungan perusahaan yang berkorelasi dengan kesejahteraan pekerja/buruh dan keluarganya sehingga pada akhirnya mampu mewujudkan keadilan sosial bagi seluruh rakyat Indonesia.

Dilihat dari fungsinya maka PKB yang berkarakter responsif, bersifat aspiratif, PKB memuat materi-materi yang secara umum sesuai dengan aspirasi dan kehendak semua pihak yang terlibat secara langsung atau tidak langsung dalam hubungan industrial. Sehingga PKB tersebut dapat dipandang sebagai kristalisasi kehendak semua pihak yang terlibat secara langsung atau tidak langsung dalam hubungan industrial (pengusaha/pimpinan perusahaan, pekerja/buruh dan pemerintah), sejalan dengan fungsi PKB yang berkarakter resposif sebagaimana dipaparkan dia atas, Suwarto berpendapat, rumusan pengaturan hak kewajiban melalui perundingan $\mathrm{PKB}$ (berkarakter responsif: penulis) mengandung banyak kelebihan, antara lain:

a. Perundingan pembuatan PKB dapat berlangsung atas kemauan kedua belah pihak untuk saling bertemu, berkomunikasi, dan saling memberi masukan. Hal ini merupakan etiket untuk keterbukaan yang merupakan unsur penting dalam membina hubungan selanjut;

b. Dalam proses perundingan terjadi interaksi aktif, saling tukar informasi dan saling mengajukan pendapat. Di sini terjadi proses saling memahami posisi pihak lain, dan akan menjurus penyamaan persepsi antara kedua belah pihak (terutama mengenai hak dan kewajiban para pihak yang bersifat syarat kerja (terms of employment): Penulis); 
Ahmad Hunaeni Zulkarkaen

Jurnal Hukum Mimbar Justitia

Vol. 4 No. 1 - Juni 2018

c. Hasil perundingan merupakan komitmen kedua belah pihak, dan seharusnya tidak ada yang merasa ditekan. Dengan demikian pelaksanaan hasil perundingan tersebut juga dapat berjalan lancar. Oleh karena itu, maka selama kurun berlakunya PKB dapat dihindari perselisihan (hubungan industrial: penulis) yang besar dan serius ${ }^{44}$ (mogok kerja, penutupan perusahaan: Penulis).

PKB yang baik harus menghindari kondisi kerja (working condition) atau hak dan kewajiban yang bersifat norma kerja (labour legislation) tetapi harus banyak memuat kondisi kerja (working condition) atau hak dan kewajiban yang bersifat syarat kerja (terms of employment), seperti bonus produksi, perumahan pekerja/buruh, kepemilikan sebagian saham perusahaan oleh pekerja/buruh melalui koperasi karyawan dan lain lain.

\section{PENUTUP}

1. Di dalam proses PKP berlaku syarat-syarat sahnya suatu perjanjian sebagaimana diatur

44 Suwarto, 2003, Hubungan..., Op.Cit, hlm. 23. dalam Pasal 1320 ayat (1) s.d ayat (4) Kitab Undang-Undang Hukum Perdata (KUHPerdata), yaitu untuk suatu perjanjian (perjanjian kerja ) yang sah harus dipenuhi 4 (empat) syarat yaitu:

a. Perizinan yang bebas dari orang-orang yang mengikatkan diri;

b. Kecakapan untuk membuat suatu perjanjian;

c. Suatu hal tertentu yang diperjanjikan;

d. Suatu sebab (oorzaak) yang halal, artinya tidak terlarang $^{24}$ tidak dilarang oleh peraturan perundangundangan, ketertiban umum dan kesusilaan.

PKP dibuat saat mulai terjadi hubungan kerja, atau pada saat pengangkatan pekerja/buruh untuk bekerja disuatu perusahaan, sehingga dengan demikian sejak awal kedua belah pihak yang terlibat di dalam hubungan kerja telah mengatahui secara jelas tentang hak dan kewajiban masing-masing. Pasal 1320 ayat 1984, hlm 134. 
Ahmad Hunaeni Zulkarkaen

Jurnal Hukum Mimbar Justitia

Vol. 4 No. 1 - Juni 2018
(1) s/d ayat
(4) KUHPerdata
tentang syarat-syarat sahnya
perjanjian berlaku untuk
pembuatan PKP.

2. PKB adalah perjanjian yang merupakan hasil perundingan antara serikat pekerja/serikat buruh atau beberapa serikat pekerja/serikat buruh yang tercatat pada instansi yang bertanggung jawab di bidang ketenagakerjaan dengan pengusaha, atau beberapa pengusaha atau perkumpulan pengusaha yang memuat syaratsyarat kerja, hak dan kewajiban kedua belah pihak. Proses perumusan PKB menganut konfigurasi politik demokratis, yaitu proses perumusannya membuka kesempatan (peluang) bagi partisipasi baik kepada pengusaha/pimpinan perusahaan maupun seluruh pekerja/buruh melalui serikat pekerja/serikat buruh secara penuh untuk ikut aktif dalam menentukan syarat kerja (term of employment) yang akan dituangkan dalam PKB, karakter produk hukum PKB bersifat responsive/populistik artinya produk hukum PKB harus mencerminkan rasa keadilan dan memenuhi harapan para pihak yang terlibat secara langsung atau tidak langsung dalam suatu hubungan industrial yaitu dalam upaya mewujudkan

produktivitas/keuntungan

perusahaan yang berkorelasi dengan kesejahteraan pekerja/buruh dan keluarganya. Pihak yang terlibat secara langsung dalam hubungan industrial, adalah pengusaha/pimpinan perusahaan dan pekerja/buruh, sedangkan pemerintah sebagai pihak yang tidak berhubungan secara langsung, tugas dan tanggung jawab pemerintah dalam suatu hubungan industrial, adalah membuat regulasi, melakukan pengawasan dan melakukan pembinaan kepada para pihak yang terlibat secara langsung dalam suatu hubungan industrial. 
Ahmad Hunaeni Zulkarkaen

Jurnal Hukum Mimbar Justitia

Vol. 4 No. 1 - Juni 2018

\section{DAFTAR ISI}

\section{A. Buku}

Abdul Khakim, 2003, Pengantar Hukum Ketenagakerjaan Indonesia Berdasarkan UndangUndang Nomor 13 Tahun 2003,Citra Aditya Bakti, Bandung.

Abdulkadir Muhammad, 2014, Hukum Perdata Indonesia, PT Citra Aditya Bakti, Bandung.

Azhary, 1995, Negara Hukum Indonesia, Universitas Indonesia, Jakarta.

Moh. Mahfud MD, 2010, Politik Hukum di Indonesia, Edisi Revisi, Rajawali Pers, Jakarta.

Muhamad Erwin, H Firman Freaddy Busroh, 2012, Pengantar Ilmu Hukum, cetakan ke 1 (satu) PT Refika Aditama, Bandung.

Ni'matul Huda, 2005, Negara Hukum, Demokrasi dan Judicial Review, UII Press, Yogyakarta.

Padmo Wahjono, 1977, Ilmu Negara Suatu Sistimatik dan Penjelasan 14 Teori Ilmu Negara dari Jellinek, Melati Study Group, Jakarta.

Bernad L, Tanya, 2011 Politik Hukum Agenda Kepentingan Bersama, Genta Publishing, Yogyakarta.

Ronny Hanitijo Soemitro, 1990, Metodologi Penelitian Hukum Dan Jurimetri, Ghalia Indonesia.
Subekti, 1984, Pokok-Pokok Hukum Perdata, PT Intermasa,Cetakan Ke XVIII, Jakarta.

Sunaryati Hartono, 1988, Hukum Ekonomi Pembangunan, Cetakan Kedua, Binacipta, Bandung.

Suwarto, 2003, Hubungan Industrial Dalam Praktek, Asosiasi Hubungan Industrial Indonesia.

Yunus Shamad, 1995, Hubungan Industrial di Indonesia, PT Bina Sumber-daya Manusia, Jakarta.

Zaeni Asyhadi, 2015, Hubungan Kerja, Hukum Ketenagakerjaan Bidang Hubungan Kerja, PT RajaGrafindo Persada, Jakarta, Cetakan ke 4.

\section{B. Peraturan}

\section{Undangan}

Perundang-

Undang-Undang Dasar 1945.

Kitab Undang-Undang Hukum Perdata.

Undang-Undang Nomor 13 Tahun 2003 tentang Ketenagakerjaan.

Peraturan Menteri Tenaga kerja Nomor 01 Tahun 1985 tentang Pelaksanaan Tata Cara Pembuatan Kesepakatan Kerja Bersama.

Peraturan Menteri Tenaga kerja Nomor 28 Tahun 2014 tentang Tata Cara Pembuatan Peraturan Perusahaan Serta Pembuatan dan Pendaftaran Perjanjian Kerja Bersama,

C. Jurnal, Makalah, Internet dan Lain-lain. 
Ahmad Hunaeni Zulkarkaen

Jurnal Hukum Mimbar Justitia

Vol. 4 No. 1 - Juni 2018

Ahmad Hunaeny Zulkarnaen \& Tanti Kirana Utami, 2016, Perlindungan Hukum Terhadap Pekerja Dalam Pelaksanaan Hubungan Industrial, Padjadjaran Jurnal Ilmu Hukum FH-UNPAD, Vol. 3 No. 2, Bandung.

Dedi Mulyadi dan Tanti Kirana Utami, 2017, The Dispute Settlement Model of regional Head ElectionPerspective Theory of Legal System in Indonesia, International Journal of Nusantara Islam UIN Sunan Gunung DJati, Vol. 5 No. 1.

Henny Nuraeny and Tanti Kirana Utami, 2015, Legal Protection Against Children Who Are Victims Of Human Trafficking In Cianjur District Studied By Human Rights Perspective, Jurnal Dinamika Hukum. Vol. 15 No. 2, Mei.

2016, The Victim Handling Model of Human Trafficking through Economic Independence, Jurnal Dinamika Hukum FH-UNSOED, Vol. 16 No. 2 Mei. 10.20884/1.jdh.2016.16.2.507.

Tanti Kirana Utami, 2017, The Position of Filling Pratama High Leadership in Cianjur Regency Under Good Governance Concept. Jurnal Dinamika Hukum FH-UNSOED, Vol. 17 No. 02, Mei.
Hukum FH-UNSOED, Vol. 18 No. 2 May.

2013 Peran Serikat Pekerja Dalam Penyelesaian Perselisihan Pemutusan Hubungan Kerja, Jurnal Wawasan Yuridika STHB, Vol. 28 No. 01 Februari.

Tim Pengajar PIH Fakultas Hukum Unpar, 1995, Pengantar Ilmu Hukum, Bandung, Bandung.

2018, Law

Protection For Indonesian

Migrant Workers Family In

Cianjur District, Jurnal Dinamika 